\title{
The Biographical Method as a Methodological Tradition in Russia: A Review of Projects and Publications ${ }^{*}$
}

\author{
Natalia Veselkova \\ Candidate of Sociological Sciences, Associate Professor, Ural Federal University \\ Address: Lenina pr., 51, Ekaterinburg, Russian Federation 620083 \\ E-mail: vesselkova@yandex.ru
}

\begin{abstract}
The biographical method in sociology and related disciplines is considered to be firmly rooted in the Western tradition of the first half of the twentieth century (the Chicago School, as well as the Polish memory contests started by F. Znaniecki), while the Russian experience remains largely neglected and unnoticed. The article presents an analytic review of six themes/ stages of this movement and their contemporary reception: (1) the N. Rybnikov Institute of Biography, (2) Historical Commissions and Societies, such as Istpart, and others, (3) the Communist Academy, (4) monographic studies and the Central Bureau of Local History, (5) the History of the Civil War and the History of Factories and Plants, Cabinets of Recordings and Memoirs, and (6) the Commission on the History of the Great Patriotic War. All of these initiatives are known to researchers, but so far, they have been studied within the narrow confines of separate disciplines, and almost without regard to the biographical method. A detailed account of these themes in the biographical method context provides us with new optics allowing to reveal the general effects of biographization as the self-reflection of modern society, either with scholarly participation or without it. The review takes into account historical realities and is placed within an interdisciplinary field. The internal continuity is traced in all analyzed projects. Their common features include the articulation of social relevance, the temporal regime, and the organizational specificity of work and its methodological characteristics. The latter are given a detailed account in terms of their relevance to the methodological precepts of contemporary humanities and social sciences.
\end{abstract}

Keywords: biographization, Oral History, reminiscences, interview, conditions of scientific rigor, Nikolai Rybnikov, Alexander Bek, historization on the march, romantic positivism

\section{Introduction: The Articulation of the Problem}

The biographical method (BM) in sociology and related disciplines is considered to be firmly rooted in Western science, primarily in the Chicago School with its model research The Polish Peasant in Europe and America by W. Thomas and F. Znaniecki (1918), The Individual Delinquent by W. Healy (1915), The Jack-Roller by C. Shaw (1930), and others. In 1921, in Poland, Florian Znaniecki launched a contest of autobiographies which was destined to lay the foundations of a unique national tradition. These episodes mark the dates of a triumphant rise of this remarkably new approach, one of research through

\footnotetext{
* The reported study was funded by RFBR, project № 19-11-0ooo1.

Translated by Dmitri Chulakov.
} 
the prism of biographies. In fact, the BM reveals and analyzes a biographical dimension that is relevant to the situation of "biographical solutions of systemic contradictions". ${ }^{1}$

Russia witnessed a similar movement in the same period of time. The six themes/ stages of this movement were (1) the Rybnikov Institute of Biography, (2) Historical commissions and societies, (3) the Communist Academy (Komakademiya), (4) monographic studies and the Central Bureau of Local History, (5) the History of the Civil War and the History of Factories and Plants, Cabinets of recordings and memoirs, and (6) the Commission on the History of the Great Patriotic War (the so-called Mints Commission), all which constitute an extremely promising field from the perspective of the BM. Yet, so far, they have been studied within the narrow confines of separate disciplines and almost without regard to this method. One of the reasons for that lies in the considerable political involvement: the above-mentioned projects absorbed and employed the key features of the epoch with its political repressions and exacerbated dictates of the Party by necessity (for the History of Factories and Plants, the process was described by Zhuravlev [1997], and for the Society of Old Bolsheviks, by Junge [2015]). As a result, the projects were curtailed, and their research potential was lost.

Intensive work with the memory of the Soviet past, started in the late-1980 by the institutions that emerged in the wake of Perestroika - such as the 'Memorial' Society, the People's Archive (the Moscow Historical and Archival Institute), the Biographical Foundation (the Sociological Institute in Saint Petersburg) and others (Golofast, 1995; Bozhkov, 2018) - gave a powerful spur to biographical research. Yet, the surge of interest in the BM in sociology and related disciplines in Russia of the 1990s, which was followed by anthropological and biographical turns as well as other fluctuations of the research field, seems to be based on the adoption of methodologies almost exclusively developed abroad (see, e.g., Rogozin, 2015). The purpose of the article is to present an analytical review of the aforementioned research practices and projects of the first half of the twentieth century and their contemporary reception. The review is arranged by interdisciplinary field and with historical realities in mind.

An attempt at an interdisciplinary study of the biographical method was made in the works of Gennady Solovyov, where the relevant steps in philosophy, psychology, sociology, history, and literary studies were outlined. However, attention was paid mainly to the potential of the BM for the practical needs of social workers and teachers (2002: 6-10, 41-57). The interpretations, which are in key with our approach, construe a range of early Soviet projects in terms of oral history, although this concept entered Russian language usage much later, and its method was considered to be borrowed from abroad. Thus, Tatyana Shcheglova shows that Soviet local history, Istpart, the History of Factories and Plants and others have gained rich experience in practical use as well as scientific and methodological grounding of what is now called 'oral history' (Shcheglova, Drozhetsky, 2014; Shcheglova, 2019). The authors of the monograph on the Mints Commission go even further, arguing that the "process of anthropologization of history" and the forma-

1. This expression by Ulrich Beck (1992: 137) is repeatedly played with and further developed by Zygmunt Bauman (2000). 
tion of oral history in Soviet Russia had occurred earlier than in the West, already in the 1920-1930s (Contribution, 2015: 10, cf.: Depretto, 2001). These publications address almost all of the projects discussed below, but only within the framework of historical studies.

For the first time, the systemic interconnection of most of these Soviet endeavors (2-5, except Cabinets) as prerequisites for the History of Factories and Plants was convincingly shown by Sergei Zhuravlev (1997: 3-27). Ilya Kalinin's description is somewhat broader. Here the movement of rabkors (worker correspondents), selkors (village correspondents) and voenkors (war correspondents), Gorky's journal Literary Studies [Literaturnaya Ucheba], Istpart, the History of the Civil War and the History of Factories and Plants, as well as the Commission on the History of the Great Patriotic War are construed as forms of "a revolutionary avant-garde project, striving to provide history with a subjective dimension, and to endow the subject with an awareness of its own historicity" (Kalinin, 2015: 643). A detailed account of these themes in the biographical method context provides a new optics allowing to reveal the general effects of biographization as a self-reflection of modern society, with academic participation or without it.

\section{Biographization and Historization on the March: Six Themes}

At the turn of the twentieth century, mass society brought about the uncertainty of rapid change, new social dynamics, and the question of the subject. According to the Polish sociologist, Marek Latoszek, extraordinary historical periods such as the 1920 s and the 1930 s with the Great Depression in the United States, Germany, or Poland (and before that, we would add the Great War, revolutions, and the Civil War in Russia, as well as the exceptional 1920s, and the Great Turn) are characterized by the abundance of autobiographical material (1989: 281-282). ${ }^{2}$ Russian futurism and a brief period of the flourishing of literature of fact proclaimed the absolute dominance of biographies and other non-fiction texts. ${ }^{3}$ The rise of the biographical method in the first third of the twentieth century in the United States encouraged a belief that this approach was a golden key which would finally open all doors for social science. The methodological principles that were formulated at that time, such as Thomas' theorem and Znaniecki's humanistic coefficient, articulated the role of the individual. Here we cannot but agree with Oleg

2. Latoszek refers to the paper on personal documents in sociology by Władysław Adamski (Adamski, 1969: 113-114, 116) - a specialist in the biographical method (see Thompson, 1994: 58). M. Latoszek himself found the biographical method very useful for his study of the events of the "Polish August of 1980".

3. In 1918, Vasily Kamensky, a Russian Futurist, claimed that "any biography of an inconspicuous archivist - even clumsily written - is a million times more interesting" than composed novels. He called for writing and publishing biographies immediately, and primarily of contemporary geniuses, but also of "anyone, yet only the living [people] with full names, the witnesses [of everything] around and of proud truth" (5). The scholar Nicolai Rybnikov, in that very same year of 1918, explained why this happened, writing: "The Great War and the events that followed it" are not coincidentally "marked by an increased interest in all sorts of reminiscences, notes, memoirs, chronicles, letters, etc." - "the hard times" encourage us to think of the increased "role of a concrete person" and "to look into the past attentively" $(1,13)$ (cf. in Kamensky, who wrote: "a Personality is asserting itself on the arena of humanity" (1918: 6). 
Bozhkov who wrote that the most important of all epistemological turns of the twentieth century marked the turn "to a common person" (2018: 6).

With all of their ambiguity, the practices which sprang up on Russian soil embodied this very trend. Viewed together, they produce an impression of an incredible boom, if not a bacchanal of reminiscences, when a multitude of evidence about the recent past and the present was gathered. Such a focus on the historical significance of the current moment and on the desire of recording it immediately in the process could be called "historization on the march". ${ }^{4}$ The studied themes intersect and overlap, and therefore can only tentatively be situated within a coherent chronology. Yet, they represent the development of the BM in Russia within the institutional framework relevant to the epoch.

(1) Let us take the work of the psychologist Nikolai Rybnikov (1880-1961) for a starting point. In 1916, he conceived of the Biographical Institute as an institution "that would collect, store, and study mass biographical material, generalize the accumulated human experience, and become a collective memory of humanity" (1943: 99; 1994: 16). As he later recalled, his appeals at conferences and in the press were "warmly and sympathetically welcomed". A biographical section was established in the Paedological Institute to listen to reports and prepare thematic collections, e. g., "Wonderful Russian women". Although it was not possible to launch full-scale elicitation and research of "mass biographical material" at that time, the scholar was sure that the Institute would certainly "be created, because there was a great need for it" (1943: 97-98).

From 1917-1930, Nikolai Rybnikov published a range of methodological articles and brochures on the prospects of the BM for various fields of science, on the typology of autobiographies, and on the methods of working with them $(1918 ; 1920 ; 1926 ; 1928 ; 1930$, and others). In 1918, under the heading of "The Biographical Institute Library", the family chronicle Gorbovskaya Khronika was published. It was written by Rybnikov's sister and associate, Maria Rybnikova, who later became a well-known philologist, methodologist, and teacher (1918). For the same series, several typewritten volumes of Rybnikov's From Generation to Generation: History of the Rybnikov Family (of the Two-Hundred-Year Period of Its Existence) were prepared. They are dated 1942 and 1943, and stored in the Rybnikov Fund in the Department of Manuscripts of the Russian State Library. Rybnikov's works on the biographical method have not been republished, except for a short fragment in the Avant-garde Museology collection (2015). A detailed account of his scholarly endeavors was published in the late 1990s (see Botsmanova, Guseva, 1997; Rybnikov, 1994; cf.: Loginova, 2001; 2006: 70; Veselkova, 2018: 207).

This stage of the development of the BM in Russia is distinguished, firstly, by the striving for a profound scientific approach to biographical research in terms of both its organization and methodology. The epistemological potential of the BM, as it was formulated in 1918, strikingly anticipates the way qualitative approach is contrasted with the quantitative one in terms of holism and depth today. Rybnikov specifically emphasized

4. The concept of "historization on the march" describes a specific temporal regime, which fuses all modes of time, normalizes everything that goes on at present, and mobilizes its participants (Veselkova et al., 2016: $166-172,236)$. 
a) integrity ("the integral inner world of a human personality as a unity in itself", which eludes experimental study), and b) the opportunity to "look into such aspects of the soul that are inaccessible to ordinary observation" $(1918: 2,5)$.

Secondly, the fundamental innovation of the BM was the inclusion of ordinary people into the orbit of research. The statement that "everyone deserves a biography, [and] every biography may be interesting for a philologist, a historian, and a psychologist" (1918: 17) still seemed a little too daring, so Rybnikov tried to justify the need for the Biographical Institute by traditionally appealing to the preservation of the heritage of great people first, and only then mentioning the significance of the lives of "average people", with the needs of positivist science in mind, which "is interested in the most typical" (1918: 13). Rybnikov's ideas were taken up by the historian Petr Kruglikov, who believed that "an average, mass person" was a true historical actor, and that contemporary science needed the method of "a theoretical biography" (1921).

By the end of the 1920 and in the early 1930s, more and more reminiscences of people from the lower classes were published, and Rybnikov subjected them to a thorough analysis in his book Autobiographies of Workers and Their Study, comparing German and Russian publications (1930). It is logical to consider this work as a response to the request for a biographical description of the victorious class, but more broadly, it serves as a manifestation of the above-mentioned turn. It is symptomatic that outside the Soviet Union, in Poland, in the same year of 1930, the almost eponymous Autobiography of a Worker by Jakub Wojciechowski was published. It was not as analytical as Rybnikov's book, yet it was not an ordinary publication, either. Wojciechowski won the competition of workers' autobiographies as announced by F. Znaniecki and the Polish Institute of Sociology in 1921. According to the experts, the book provided "a sufficient argument" in favor of "the methods of personal documents" in social sciences (Kupriyanov, 2008: 67-68; see also: Thompson, 1994).

Thirdly, a number of significant changes were made to the methodology of empirical biographical research. Namely, (a) the substantiation of the active role of a researcher. It is often not enough just to gather the exiting documents; it is necessary to bring them to life and preserve them (Rybnikov, 1918: 13, 1928: 93), for example, by encouraging people to keep diaries, by asking parents to collect their children's drawings and take notes, and finally conducting surveys. For sociologists, it was a routine, but for psychologists, ${ }^{5}$ it was less common. Even for today's historians, they are to be reminded that oral sources are not so much collected but created at the request of the researcher (Shcheglova, 2019: 94). In later works, Rybnikov introduced the terminology that is still of importance today, distinguishing between provoked and unprovoked autobiographical materials (1930); (b) calling to collect diverse biographical materials: "biographies, autobiographies, diaries, family archives, notes, reminiscences, letters, obituaries, curriculum vitae, photo-

5. In his Autobiography, Rybnikov denounces the lifeless system of teaching psychology at Moscow University, which started to change only in 1907 thanks to G. I. Chelpanov, who organized a seminar and a psychological laboratory — the embryo, as Rybnikov puts it, of the future Institute of Psychology (1942: 273-291; 1994). 
graphs, [specimens of] handwriting, phonograms, and artistic products", including children's drawings (1918: 12; 1926). In fact, Rybnikov speaks of the triangulation of sources (implying the triangulation of methods for collecting and analyzing information, which, as we know today, form the foundation for the validity of such research); and (c) the diversity of sources, coupled with their mass character, provides for what contemporary ego-document specialists call the "cumulative effect" when working "with a large source complex" (Surzhikova, 2017: 25, 2020: 54.20 et seq.). "[T] he very essence of the biographical method is such that it needs mass collection of material" to smooth out the errors of subjectivism of the biographer, and the inaccuracies and incompleteness of biographies. For processing mass sources, Rybnikov insistently suggests the still very new then "method of correlation", referencing his overseas colleague, Ch. Spearman (1918: 12).

Exceptional attention given to the "aroma of individuality" that is combined with an unconditional faith in statistics (Ibid.) gives the positivism of that period a romantic flavor. This romantic positivism is clearly manifested in Rybnikov's work, as well as in other initiatives of that time.

(2) At the very beginning of the 1920s, a number of Commissions on History and Societies emerged, such as the Commission on the History of the October Revolution and the Communist Party (Istpart), the Commission on the History of the Trade Union Movement (Istprof), the Commission on the History of the All-Union Leninist Young Communist League and the Revolutionary Youth Movement (Istmol), the Society of Former Political Convicts and Exiles, and the Society of Old Bolsheviks. The Commissions were established top-down on the initiative of the state, while the Societies were a grassroots movement. ${ }^{6}$ However, all of them worked for a decade, and some even longer, to capture the history of what was considered to be a revolutionary turn of world significance, and were instructive for both the audience abroad, for the peoples who would take this path later, and for internal recipients as education of the Soviet youth in the right spirit.

To this day, the amount of research on these institutions reflects their place in the Soviet political hierarchy. Istpart has been the most extensively studied (see the review by Lazareva 2011; Corney 1998; 2004), while Istprof (Gilmintinov, 2018; 2019a; 2019b), the Society of Former Political Convicts (Vasilieva, 2011; Junge, 2015), the Society of Old Bolsheviks (Pivovarov, 2018) and Istmol deserved much less attention. Researchers claim that the activities of Istpart, or Istprof, etc., were driven by the need to stand in competition with the West in the interpretation of the revolution, providing "a new model of historical memory with a source base and a new historical concept" (Klopikhina, 2019), ${ }^{8}$ and ultimately to legitimize the regime and mobilize the population.

6. Although the Society of Old Bolsheviks was founded "in direct subordination to Istpart", and according to Mark Junge, Istpart was a competitor to the Society of Former Political Convicts and other organizations, all of them interacted closely (2015: 54-55).

7. Cf. a short list in the review of the book by F. Corney (Novikova, 2007: 466).

8. It seems that this characteristic, given by V. Klopikhina to Istpart, can be fairly extended to all other establishments. 
The routine dimension of their work is of special interest for the BM: it is necessary to find and sometimes withdraw relevant documents from archives and libraries, photograph historical sites, register participants of events, collect artifacts from them, and encourage them to give their reminiscences. Incoming materials were actively published (in 1930, Rybnikov mentioned the specificity of Ispart publications), and put on display in exhibitions and new museums (see, for example, Krasilnikova, 2016).

In 1924, in preparation for the twentieth anniversary of the 1905 revolution, the chief Soviet historian, Mikhail Pokrovsky, made a methodological statement which "legitimized" the value of reminiscences as a historical source; this step is especially appreciated by oral history experts (Shcheglova, Drozhetsky, 2014: 258). Like in Rybnikov's case, the conditions of scientific rigor were ensured by the mass and organized elicitation of memories, but this time, they were not just provoked, but compiled according to a certain plan (a questionnaire) of collecting evidence. A draft questionnaire or, in more up-todate terminology, a guide to a semi-formal interview on the Russian Revolution of 1905 was also published. Pokrovsky specifies the flexibility and variability of his questionnaire, and addresses not so much the informants as those "who will gather information from the working masses" (1924a; 1924b: 14). In this regard, historians distinguish between more independent memoirs of the first half of the 1920s ("self-recordings" and printed transcripts of the original manuscripts), and more unified later reminiscences compiled according to the Istpart plan (Krasilnikova, 2016: 93, cf.: Narsky, 2017: 77).

(3) The Communist Academy, a Section of the History of the Proletariat in the Institute of History, used the BM in the historical research of the proletariat in the USSR, which was construed as the "scientific 'biography' of the proletariat". This endeavor was encouraged by M. N. Pokrovsky in the end of the 1920s, and was conducted under the supervision of A. M. Pankratova. Several Commissions were formed in the Section, including a Questionnaire-Biographical and a Monographic one, on the study of individual enterprises (Ignatenko, 1975: 10, 12; Chaadaeva, 1930). The value of autobiographies and memoirs was determined by the immediacy and concreteness of observations, but according to the head of the Questionnaire-Biographical Commission, Boris Gorev, they had to be no more than 60 years old: it was essential to make haste with eliciting precious evidence (Gorev, 1930).

The memoir materials, which had been accumulated earlier by Istpart, Istprof, and others were found to be of little use due to their "spontaneous nature", and the task was to develop a new methodology. The Commission's efforts were to be focused on working with factory archives, ordering autobiographies of the figures of the revolutionary movement, organizing detailed interviews ("surveys") of old workers, and conducting a less detailed but broader polling of "workers of the entire [Soviet] Union" (Chaadaeva, 1930: 148; Gorev, 1930: 180-181; Ignatenko, 1975: 17-18). In the article by Olga Chaadaeva, the conditions of scientific rigor were specified: a) to identify the role of the narrator in the events described, b) to separate personal experience from what was known from others, c) to discern current evaluations from the past ones, and d) to verify autobiographical 
materials by archival data. A step-by-step description of work at these enterprises and a number of procedural recommendations were also given (1930).

At this stage, the "scheme-questionnaire" became even more extensive. In comparison with Pokrovsky's questionnaire, it was supplemented by a fundamentally-novel block on biography and everyday life. The questions were accompanied by detailed notes, and the guidelines were very close to the current instructions for a narrative biographical interview (Sobiraniye, 1931). These guidelines were used at two Moscow enterprises, the Trekhgornaya Manufactory, and the 'Hammer and Sickle' factory. Reminiscences, that is, the 'autobiographies' of workers, were taken down in shorthand or simply recorded during 2-3, or sometimes more, meetings at their place of residence. The format varied from a much desired "live and smooth narration of the worker" to answering the interviewer's questions. Some informants wrote down their reminiscences themselves, checking with the proposed scheme. For each plant, a collection of summarizing articles and selected autobiographies was published, while the source materials were accumulated in the fund of the Questionnaire-Biographical Commission in the research room of the Communist Academy Library, and were declared to be available for anyone who wanted to use them (Anketno, 1930, 1931).

Thus, the systematic work with reminiscences undertaken at the second (Istpart and others) and third (the Communist Academy) stages embodied the initial design of Rybnikov and Pokrovsky, in order to purposefully generate the necessary materials and compile a database. This was a scientific breakthrough, which anticipated, according to J.-P. Depretto, the field of contemporary “Oral History" (2001: 84).

(4) Through the efforts of the historians Anton Bolshakov, Mikhail Phenomenov, and others in the 1920s, monographic studies of the village were carried out (Tsvetkova, 2016; a brief review: Kulachkov, 2014: 10). Igor Vernyaev notes their relation to the works of the Zemstvo statisticians, on the one hand, and Teodor Shanin's reflexive peasant studies, on the other (2005). Factories and plants were studied by special commissions of the Moscow Regional Trade Union (since 1928), the Central Bureau of Local History (from 1929-1930), and the Communist Academy (since 1930) (Ignatenko, 1975: 20-29; Sklyarenko, 1986: 7-11; Zhuravlev, 1997; Zhadaeva, 2018: 106-107). In the Communist Academy journal The History of the Proletariat in the USSR, a section titled "Monographic Research of the History of Industrial Enterprises" appeared, where methodological articles and programmatic documents were published (Shcheglova, Drozhetsky, 2014).

In local history studies, as well as in other fields, the emphasis was on the mass involvement of the population and assistance to the national economy (Smirnova, 2016). In 1930, the Central Bureau of Local History announced a competition for the best writing about a factory or a plant in the form of a monographic description of either its current state, its historical development, or both. Popular scientific works were expected by September 1, 1930, and research works by January 1, 1931, consisting of from 8 to 15 printer's sheets, respectively (Pravila, 1930). The Central Bureau of Local History was very proud that it distributed 9,000 copies of a color poster with the terms of the competition. However, campaigning alone was not enough, so methodological and instructional brochures 
called Monographic Study of Factories and Plants (Promyshlennaya, 1930), and Study Your Plant were published in large print runs (Krandievsky, 1932).

Planned for the end of 1930, "the local history five-day period" included, among other things, thematic evenings of reminiscences (Postanovleniye, 1930), which could be viewed as a point of intersection of the monographic approach (case study) and the BM (see Veselkova, 2017). Turning to letters was less common; therefore, Pavel Bazhov's proposal, who was then working in the Urals in the Peasant Newspaper [Krestyanskaya Gazeta], to use letters as a local history source (Bazhov, 1927; on letters see: Veselkova, 2018) is especially interesting.

A number of visits to Moscow enterprises urged the Soviet Local History [Sovetskoe kraevedenie] journal to claim that the idea was in the air and "in some cases began to be implemented independently". Several examples were given when enthusiasts began studying the history of their own factories on their own initiative. At the grassroots level, the interest was primarily focused on the historical and social characteristics of enterprises in contrast to the expected industrial aspect (Mirskaya, 1930), so the monographic description of the enterprise turned into its biography. For example, from the North Caucasus, it was reported of a compiled 'autobiography' of a kolkhoz (Pyatigorskiy, 1931). It was not possible to study all of the enterprises in one year, but, according to the report of the Industrial section of the Central Bureau of Local History from 1929-1930, the competition still gathered 30 manuscripts (Sklyarenko, 1986: 11). Gradually, the monographic work merged into Gorky's History of Factories and Plants (Ignatenko, 1975; Zhuravlev, 1997: 19-27), and several manuscripts from the local history contest ${ }^{9}$ were also passed over there.

(5) Conceived by Gorky in the late 1920 among a number of other "Histories" (Moskovskaya 2016; Spiridonova 2016), in 1931, the History of the Civil War (HCW) and the History of Factories and Plants (HFP) received support in the form of resolutions of the Central Committee of the Bolshevik Party, and soon the spreads of all newspapers were allotted to the Instruction-Plan. The ultimate goal, according to Gorky, was to give mass audience "a point of view" on key events in Soviet history (Zelenov, Brandenberger, 2017; Moskovskaya, 2018). In the future, HFP was seen as the "Institute for the Study of Growth and Development of Socialist Industry in the Union of the Soviets" (Zak, Zimina, 1959: 37). David Brandenberger assumes that these and other projects of the 1930s managed to make the past "useful" due to the "cult of heroes", i. e., by showing not impersonal schemes, but concrete people and events (1999: 86; 2017a: chap. 4; 2017b).

Both the HCW and HFP succeeded previous projects and maintained contact with them, but just as the Communist Academy could not use the materials from Istpart and the Societies of Old Bolsheviks and Former Political Convicts, so factory histories prepared by the Communist Academy did not fit the new format. Gorky rejected them as

9. In the History of Factories and Plants, these manuscripts were ostracized as "the examples of obscurantism" due to "the authors' hostility to socialist building" and the general lack of "political acuteness" (Shushkanov, 1932: 177). 
"way too scholarly". ${ }^{10}$ It was assumed that the main creators of these Histories were to be immediate participants of the events, the workers. The qualifications of the invited authors were also uneven, so the methodological disputes were by necessity enriched with concrete recommendations. The The History of Factories bulletin, published by the editors of HFP from 193s2-1934, sheds light on the techniques of eliciting information both from archives and from "recording reminiscences" in interviews (Gaisinovich, 1932a, 1932b, 1932c; Rozhkova, 1932; Rabinovich, 1933; see: Shcheglova, Drozhetsky, 2014). In 1933, six brochures In Support of the Authors, each about ten pages long, were published (Akhun, Lukomsky, 1933; Grekulov, 1933; Rozhkova, 1933a, 1933b; Tretyakov et al., 1933; Programma, 1933).

In 1931, at Kuznetskstroy, the writer Alexander Bek became an ardent supporter of the method of "conversations", which was the biographical interview in its essence. ${ }^{11}$ Years later, in his Postal Prose, he would use his correspondence with his wife Lydia Toom, who organized the HFP editorial office at Kuznetskstroy. ${ }^{12}$ In this book, he would give a detailed account of the Moscow writers' brigade (1993; see also; 1962b). Venerable authors were reluctant to get involved in such projects, but for beginners like A. Bek and V. Kovalevsky, HFP became a powerful career boost.

The method of biographical conversations developed at Kuznetskstroy by A. Bek and L. Toom was successfully used later, for example, from 1934 in the Cabinet of Recordings of the newspaper "For Industrialization" when the prominent figures of industry were interviewed, and in the Cabinet of Memoirs, ${ }^{13}$ created on the initiative of M. Gorky in the editorial office of the "People of Two Five-Year Plans" collections. With the commission of the Military Publishing House [Voenizdat], the interviewers (besedchiki) gathered "colossal material covering the entire history of aviation" (Transcript, 1957: 33, 37-38). In A. Bek's works, a common motif of a conversation between the author and his protago-

10. See Gorky's reviews of the manuscripts by historians Zeltser, Paradizov, Rozhkova about the Trekhgorny manufactory (Zak, Zimina, 1959: No. 59, No. 60). Historians N. A. Rozhkov and M. K. Rozhkova studied the Trekhgorny (Prokhorov) manufactory back in the 1920 from the economic and political perspective (Ignatenko, 1975). Although M.K. Rozhkova's article in the Communist Academy collection was written on the basis of 'autobiographies' of workers, HFP published the book of S. M. Lapitskaya, who used the same data, but wrote about everyday life and not the economy (Rozhkova, 1930; Lapitskaya,1935). The works of writers were also severely criticized when they lacked a documentary basis (Zak, Zimina, 1959: No. 78; Zhadaeva, 2018: 120).

11. At that time, the term "conversation" was more preferable than "interview". It is suggestive that in the wake of Perestroika, the first Russian article about qualitative interviewing in the Sociological Studies journal also defined this method as a conversation (Ivanov, 1989).

12. Their grandiose work was followed by only two preliminary books (Bek, 1933; Toom, 1934), but a lot of material was gathered. O. Belousova mentions about 250 recorded reminiscences, which are deposited in the archives of Novokuznetsk (2004); see also A. Bek's Fund in the Russian State Archive of Literature and Art, and Kuznetskstroy's History Fund in the State Archive of the Russian Federation.

13. It is noteworthy that Igor Orlov translates the Oral History Research Office, which was created in 1948 at Columbia University and is believed to lay the foundations for oral history, as The Oral History Cabinet (Orlov, 2010: 44-45). A decade earlier, its organizer, Allan Nevins, in the preface to the first edition of his book The Gateway to History, had expressed an idea to retrieve information on recent past, within half a century, directly from contemporaries (1938). Paying the Russian tradition of using oral sources its due, I. Orlov, in contrast to T. Shcheglova and others, still prioritizes the American Cabinet. 
nist can easily be traced when the writer inquires about his character's life. In the novel The Talent (The Life of Berezhkov), the work of the "Cabinet of Memoirs" in 1936 was described, and in Postal Prose a real instruction on "the method of conversations" was provided (Bek, 1991b: 7-11; 1993: 417-418). After Gorky's death, the Cabinets subsided, but A. Bek considered them to be "a constantly replenished repository of human documents", which was absolutely necessary for writers and historians. He repeatedly called for the revival of this "institution for the study of life" (Bek, 1962a: 168; Grudtsova, 1967), or "the first Soviet Storybank", as it would be called in the new century (Gopius, 2019).

Vyacheslav Kovalevsky was invited by Gorky to HFP (the historical short novel about the Trekhgorny manufactory came out after the series was closed (Kovalevsky, 1939)). The experience of HFP was of use for both him and Bek in their work as war correspondents. The material was later used in Kovalevsky's Notebooks from the Map Case (1968) and Bek's Volokolamsk Highway (1991a). ${ }^{14}$

HCW and HFP were strongly intersecting, and in 1933-1937, they operated within the united publishing house The History of the Civil War and the History of Factories and Plants. HCW was planned to be a 15-volume edition, and from 1935 to 1960, five volumes of the conceived 15-volume edition of HCW were published. Meanwhile, in 1935, the colossal number of 300,000 copies of its first volume appeared in print, and the next year, 500,000 copies of its second edition came out. Before its liquidation in January, 1938, the HFP's publishing house issued 30 books, including six methodological brochures. After the XX Congress of the CPSU, there were attempts at starting HFP anew, with appeals to the authority of Gorky (Iokar, 1957; Rozanov, 1958; Zak, Zimina, 1959; Rogachevskaya, 1963; Panfilova, 1974). The wave of publications on the history of enterprises eroded the initial high standards (Argutinskaya, 1965), but it satisfied the demand for a return to the "right" (Leninist and Gorky) traditions. More generally, the need was for a collective identification and for inscribing oneself in history by scaling social memory.

Analytical works and collections of documents on the HCW project have been published in recent years (Bystrova, 2017; Zelenov, Brandenberger, 2017; Moskovskaya, 2018; Iroshnikov et al., 2018; cf. Malysheva, 2001). As for HFP, new materials can be found in the correspondence of Gorky (e.g., Gorky, 2018). A full-text database of reminiscences on particular factories (Rudenko, 2017) has been created. In terms of historiography, Sergey Zhuravlev's work (1997, see also Zhuravlev, 1989) remains to be the most complete. Philologists and cultural historians traditionally situate these Histories in the dynamics of Soviet socialist realism (Dobrenko, 2007: ch. 2 and 4; Clark, 2002; Clark, 2004; Litovskaya, 1998). Published in an international collection, Katerina Clark's article places HFP in a wider context of working-class literature of different countries (2017). The Cabinets are still waiting for their researchers.

Despite the watershed of the 'Great Terror' and then the War, experts find signs of continuity in the research work on historicization: Tatyana Shcheglova argues that oral

14. On the use of conversation practices by A. Bek in the History of Factories and Plants and the Mints Commission: Lotareva, 2014: 152; Shcheglova, Drozhetsky, 2014: 257) and in more detail: Zhuravlev, 2015: $235-241$. 
history practices were developing in the following years, in particular, in the Commission on the History of the Great Patriotic War (2019: 97).

(6) The Commission on the History of the Great Patriotic War, or the Mints Commission, ${ }^{15}$ was formed in December, 1941. Initially, it was conceived as a chronicle of the defense of Moscow, but in the future, Isaak Mints planned to establish the academic Institute of the Great Patriotic War. In Leningrad, in the first months of the siege, the idea of gathering current documents came up. According to an employee of the local Istpart, "reports, factory papers, newspaper articles, wall newspapers, leaflets, protocols, resolutions, posters, letters, diaries" were to be collected (cit. ex: Chistikov, 2019: 11). At working meetings, the Leningrad Commission members explained the importance of reminiscences, diaries, and autobiographies, and prepared the first collections of documents and materials (Sobolev, 2012: 74; Ganzenmüller, 2019: 416-418). The difference from previous projects was that the reminiscences were recorded at the front and in the rear. As a rule, they were still fresh and elicited by professionals, that is, historians and writers.

Publications about the Commission that appeared in the (late) Soviet period (for a historiographical review, see: Lotareva, 2014; Budnitskii, 2018) emphasized a large number of interviews with high-ranking military commanders, which was obviously a sign of the value of the information elicited. Later, though, on the contrary, the interest and expected value shifted to the lower levels of the social hierarchy. Describing the work of the Commission in Stalingrad, Jochen Hellbeck gives a detailed account of the categories of informants. Along with generals, staff officers, and commanders, there were ordinary Red Army soldiers, commissars and agitators, sailors, nurses, and civilians such as engineers, workers, and a woman who worked in the kitchen (Hellbeck, 2015: 12). Currently, the Commission's website is operating, ${ }^{16}$ and the materials are gradually being brought into circulation. It would be interesting to compare them with the data of the Harvard project which was implemented by American scholars shortly after the war (some data of the Mints Commission were also obtained in this period), through formalized and semiformalized interviews with former Soviet citizens who stayed in the Allied occupation zone (Inkeles, Bauer, 1959; Kodin, 2003; Budnitskii, Novikova, 2018); a small step in this direction has been made by Oleg Budnitskii in his recent publication (2018).

Alexey Kurnosov, who specializes in the Mints Commission, pointed out its continuity with Istpart, HCW, and HFP, arguing that their experience was adopted by various institutes, museums, and archives (1974: 118; Arkhangorodskaya, Kurnosov, 1982: 225). In a recent collective publication of the Institute of History of Russia of the Russian Academy of Sciences, the connection of the Commission with "the rich experience of previous

15. A common name after the actual leader I. I. Mints, another variant after the name of the official head - "The Commission of A. F. Aleksandrov" (see Chistikov, 2019). The Estonian Republican Commission was led by the historian H. H. Kruus (1971), who became the Minister of Foreign Affairs of the ESSR for several years after the war.

16. The Commission on the History of the Great Patriotic War (http://komiswow.ru/). A part of its collection is available on the website "Stalingrad" (http://stalingrad.rusarchives.ru/razdely/stenogrammy-beseds-uchastnikami-bitvy-iz-arhiva-komissii-po-istorii-velikoy-otechestvennoy-voyny), and is included into the bigger oral history project "Soviet \& Post-Soviet Wars" (Sieca-Kozlowski, 2019). 
historical initiatives of the 1920 s and 1930s" is represented in detail, taking into account the local history movement and the Communist Academy's Questionnaire-Biographical Commission. In fact, Isaac Mints was at the head of the History of the Civil War secretariat from 1931 to 1947, and the Commission on the History of the Great Patriotic War, which was created on his initiative, was even located in the same room with HCW (Contribution, 2015: 9-14; Lotareva, 2014: 123-124). In the draft of the Instruction to the military units of $1942,{ }^{17}$ the work on their history was presented as a continuation of HCW. Apart from Mints and other 16 members of HCW who also worked in the Commission on the History of the Great Patriotic War, ${ }^{18}$ there are other intersections on the personal level. For example, Olga Chaadaeva, who gathered reminiscences in the early 1930 in the section of the History of the Proletariat in the Communist Academy, and Alexander Bek, who we know from the Moscow writers' brigade of HFP at Kuznetskstroy and the Cabinets of Recordings and Memoirs, also worked in the Mints Commission. It would not be an exaggeration to claim that the Commission on the History of the Great Patriotic War is successive to all the described biographical projects (1-5), starting from the intentions of N. Rybnikov and up to the collections of transcripts celebrated by A. Bek. In my opinion, all of them have the following four features in common:

(1) The articulation of social relevance: discussions usually focus on their educational and scholarly significance, but the projects themselves emphasized the social request for historicization and biographization. As it was said previously, it was high time to organize the spontaneously-spreading practices (the publishing of memoirs, compiling histories of organizations, etc.) to raise them to a new level, to be either scientific (as in Rybnikov's case, or in monographic local history studies, and in the Commission on the History of the Great Patriotic War, partly in HCW and HFP), or ideologically verified (Istpart, Istprof, Istmol, HCW, and HFP). In all cases, it had to be of mass character.

(2) The temporal regime: the projects were usually arranged on the go to lay the groundwork for future research (for example, the second edition of the Biographical Dictionary of the Fallen Revolutionaries was published in 1924 by Istpart, and was presented as "a preliminary collection of materials requiring further study" (Lezhava, Rusakov, 1924). In terms of procedures, there were clear connections, yet not absolute, to the memorable dates and places. An example of this is the Twentieth Anniversary of the 1905 Revolution (the exception was prompt research on new construction sites in HFP and in the Commission on the History of the Great Patriotic War). The commemoration of memorable dates and places is usually analyzed in terms of the formation of a new "collective memory landscape" (Krasilnikova, 2015; 2016: 343), but it is worth paying attention to the elicitation of information in situ, when the potential of the place and space is included in the study.

17. See this project and a number of other documents: Zhuravlev, 2015.

18. Members of the Commission // Commission on the History of the Great Patriotic War of the USSR Academy of Sciences 1941-1945 (http://komiswow.ru/?q=chkomis). 
(3) Organization of work vertically and horizontally, carried out by a head office, its regional divisions, and a wide territorial and industrial network. This is the striving for fundamentality through the establishment of research "Institutes".

(4) Methodological characteristics (Zhuravlev, 2015: 9-14) of the analyzed projects show that the foundations of the BM were developed. These foundations are directly related to the methodological principles and subjects of contemporary humanities and social sciences. This feature can be broken down into four additional points:

(a) the significance of the biographical experience of not only outstanding individuals but also of 'ordinary people', their involvement not only as informants, but to a lesser yet systematic extent, as participants in the elicitation and subsequent processing of information, could be referred to as the principles of participatory research and action research;

(b) the value of the grassroots and the insider perspective, with a focus not only on the eventual and structural aspects of the "Big History", but also on living particularities and details, and on the emotions and experiences could be correlated with the themes of everyday life and the anthropological turn;

(c) the participation of specialists in various fields, such as historians, archaeographers and archivists, local historians, writers, journalists, photographers, artists, and printers, as well as party functionaries and activists, could be construed as research triangulation, but with the peculiarity that such cooperation was aimed at writing books for a wide range of readers, and;

(d) the triangulation of sources and methodologies is manifested in the use of heterogeneous data obtained by various methods with a large share of initiative documentation and sources of personal origin, including the provoked ones, i. e., written by order of the researchers of autobiographies or reminiscences, as well as memories given orally and recorded at individual and collective interviews and discussions. It is supplemented by the compilation of comprehensive databases, referred to as "factographic card-catalogues" (Zak, Gorodetsky, 1987; Lotareva, 2014: 126; Zhuravlev, 2015: 10).

\section{Conclusion}

Viewed from today, the striving for the mass expansion and establishment of the special Institutes during the first half of the twentieth century may seem absurdly gigantomaniacal and eccentric, even if their political and ideological charge is left out. At the same time, promising seeds have found fertile soil. A hundred years ago, the Biographer almanac, conceived by Nikolai and Maria Rybnikov for "a comprehensive study and systematization of Russian biographical literature" (1918: 16), never came into being. Yet, it seems to have found its embodiment in Avtobiografi, the online journal on "life stories and self-representations in Russian culture", which has been published since 2012 by the University of Padua (Criveller, 2012: 11). From the start of Perestroika, new types of archives, museums, and other research initiatives began to appear in academic institutions (Bozhkov, 2018). Take, for example, the grandiose 15-year-long project of Boris Doktorov, which gathered the biographies of seven generations of Russian sociologists $(2013$; 2014; 
2020). Along with such Internet resources as Lived Through [Prozhito], Oral History, Open List, EtoRetro.ru and others (some of them are of a more general character, while others have a narrower thematic and local historical focus), these projects and institutions actively democratize relations with the past (Sobolevskaya, 2019; Abramov, 2011), and, at the same time, serve as a useful support for specialists (see, e.g., Hellbeck, 2017: 416-417). The seemingly-impossible combination of the mass and the professional finds its implementation in the "constantly replenished repositories of human documents", which N. Rybnikov, A. Bek, and probably other personages of this review so passionately aspired to.

Until now, the presented initiatives of the first half of the twentieth century have been studied within the narrow confines of separate disciplines; Rybnikov's legacy has been studied in psychology, and the rest have been of interest for history and literary studies, practically without regard for sociology, anthropology, etc. For the most part, these studies have been aimed at the information retrieval or the denunciation of ideological bias. The given review allows us to conclude that these projects constitute a significant part of the general movement of biographization which has manifested itself in different countries and continents since the beginning of the twentieth century, and which is known today as the BM (and the related sphere of oral history). The abundant experience of the Russian initiatives of the first half of the twentieth century definitely deserves a new interpretation, and the BM is an appropriate framework for this endeavor.

\section{References}

Abramov R. (2011) “Sovetskiy cherdak" rossiyskoy blogosfery: analiz nostal'gicheskikh virtual'nykh soobshchestv ["Soviet Attic" of the Russian Blogosphere: Analysis of Nostalgic Virtual Communities]. Interaction. Interview. Interpretation, vol. 5, no 6, pp. 88-102.

Akhun M. I., Lukomsky V. (1933) Vyyavleniye arkhivnykh materialov dlya istorii fabrik i zavodov (Po fondam Leningr. otd-niya Tsentr. istorich. arkhiva) [Identification of Archival Materials for the History of Factories and Plants (According to the Funds of the Leningrad Department of the Central Historical Archive)], Moscow: The History of Factories.

Anketno-biograficheskaya komissiya (1930) Predisloviye [Preface]. Rabochiye Trekhgornoy manufaktury $v 1905$ godu [Workers of Trekhgorny Manufactory in 1905], Moscow: Publishing House of the Communist Academy, pp. 3-6.

Anketno-biograficheskaya komissiya (1931) Ot anketno-biograficheskoy komissii [From the Questionnaire-Biographical Commission]. Rabochiye zavoda 'Serp i molot' (b. Guzhon) v 1905 godu [Workers at the Hammer and Sickle Plant (former Guzhon) in 1905], Moscow: Publishing House of the Communist Academy, pp. 3-5.

Argutinskaya N. K. (1965) O sozdanii knig po istorii fabrik i zavodov [On the Creation of Books on The History of Factories and Plants]. Kniga: Issledovaniya i materialy [Book: Research and Materials], Moscow: Kniga, pp. 58-75. 
Arkhangorodskaya N. S., Kurnosov A. A. (1982) O sozdanii Komissii po istorii Velikoy Otechestvennoy voyny AN SSSR i yeye arkhiva (K 40-letiyu so dnya obrazovaniya) [About the creation of the Commission on the history of the Great Patriotic War of the USSR Academy of Sciences and its archive (On the 4oth anniversary of the founding)]. Archaeographic Yearbook for 1981, Moscow: Nauka, pp. 219-229.

Bauman Z. (2000) Liquid Modernity, Cambridge: Polity.

Bazhov P. (1927) Krayevedcheskiye istoki (Krest'yanskiye pis'ma v gazete) [Local History Sources (Peasant Letters in the Newspaper)]. Ural'skoye krayevedeniye, no 1, pp. 23-28.

Beck U. (1992) Risk Society: Towards a New Modernity, London: Sage.

Bek A. (1933) Glavy istorii Kuznetskstroya (1913-1920 gg.) [Chapters of the History of Kuznetskstroy (1913-1920)] (as a manuscript, for discussion), Moscow: State Publishing House "The History of Factories".

Bek A. A. (1991a) Volokolamskoye shosse [Volokolamsk Highway]. Izbrabnnye proizvedenia. T. 2 [Collected Works, Vol. 2], Moscow: Khudoz. lit., Russian Soviet PEN Center.

Bek A. A. (1991b) Talant (Zhizn' Berezhkova) [The Talent (The Life of Berezhkov)]. Izbrabnnye proizvedenia. T. 3 [Collected Works, Vol. 3], Moscow: Khudoz. lit., Russian PEN Center.

Bek A. A. (1993) Na drugoy den'; Takova dolzhnost'; Pochtovaya proza; Roman o romane: iz dnevnikov (1964-1972) [The Next Day; Such is the Position; Postal Prose; A Novel about the Novel: From Diaries (1964-1972)]. Izbrabnnye proizvedenia. T. 4 [Collected Works, Vol. 4], Moscow: Khudoz. lit., Russian PEN Center.

Bek A. (1962a) Vash korrespondent poterpel neudachu [Your correspondent failed]. Schastlivaya ruka [Happy Hand], Moscow: Soviet writer.

Bek A. (1962b) Stranitsy zhizni [Pages of life]. Schastlivaya ruka [Happy Hand], Moscow: Soviet writer, pp. 169-179.

Belousova O. A. (2004) Inostrannyye rabochiye i spetsialisty na Kuznetskom metallurgicheskom kombinate (1929-1939 gg.) [Foreign Workers and Specialists at the Kuznetsk Metallurgical Plant (1929-1939)] (PhD Thesis), Tomsk: Tomsk State University.

Botsmanova M. E., Guseva E. P. (1997) Nikolay Aleksandrovich Rybnikov (obzor arkhivnykh materialov) [Nikolay Aleksandrovich Rybnikov (review of archival materials)]. Voprosy Psychologii, no 6, pp. 96-108.

Bozhkov O. (2018) Ot biografiy k svidetel'stvam “ochevidtsev” [From Biographies to Certificates «eyewitnesses»]. International Journal of Cultural Research, no 1, pp. 6-11.

Brandenberger D. (1999) Proletarian Internationalism, "Soviet Patriotism" and the Rise of Russocentric Etatism During the Stalinist 1930s. Left History, vol. 6, no 5, pp. 80-10o. Brandenberger D. (2017a) Krizis stalinskogo agitpropa: propaganda, politprosveshchenie i terror $v$ SSSR, 1927-1941 [Propaganda State in Crisis: Soviet Ideology, Indoctrination, and Terror under Stalin, 1927-1941], Moscow: ROSSPEN.

Brandenberger D. (2017b) Stalin's Rewriting of 1917. Russian Review, vol. 76, no 4, pp. 667-689.

Budnitskii O. V. (2018) A Harvard Project in Reverse: Materials of the Commission of the USSR Academy of Sciences on the History of the Great Patriotic War - Publica- 
tions and Interpretations. Kritika: Explorations in Russian and Eurasian History, no 1, pp. 175-202.

Budnitskii O. V., Novikova L. G. (eds.) (2018) Garvardskiy proyekt: rassekrechennyye svidetel'stva o Velikoy Otechestvennoy voyne [The Harvard Project: Declassified Evidence of the Great Patriotic War], Moscow: ROSSPEN.

Bystrova O. V. (2017) Izdatel'skiy proyekt M. Gor'kogo "Istoriya grazhdanskoy voyny": po materialam arkhiva A. M. Gor'kogo (IMLI RAN) i RGASPI [Gorky's Editorial Project The History of the Civil War: on the Materials of the A. M. Gorky (IWL RAS) and RGASPI Archives]. Studia Litterarum, no 4, pp. 378-393.

Chaadaeva O. (1930) O pervom opyte po sobiraniyu avtobiografiy rabochikh [About the first experience in collecting autobiographies of workers]. Istoriya proletariata SSSR, no 2, pp. $148-155$.

Chistikov A. N. (2019) "My zhivem v interesnoye vremya..." Pervyye popytki sbora materiala o blokade Leningrada v 1941-1942 gg. ["We are living in interesting time...": The first attempts in collecting of Leningrad's siege documents in 1941-1942]. Bitva za Leningrad 1941-1944 gg.: podvig goroda-geroya $v$ Velikoy Otechestvennoy voyne [The Battle of Leningrad 1941-1944: feat of the hero city in the Great Patriotic War] (eds. G. L. Sobolev et al.), Saint Petersburg: Nestor-History, pp. 5-14.

Clark K. (2002) Sovetskiy roman: istoriya kak ritual [The Soviet Novel: History as Ritual], Ekaterinburg: Ural State University.

Clark K. (2004) "The History of the Factories" as a Factory of History: a Case Study on the Role of Soviet Literature in Subject Formation. Autobiographical Practices in Russia - Autobiographische Praktiken in Russland (eds. Hellbeck, Heller), Göttingen: V\&R, pp. 251-279.

Clark K. (2017) Working-Class Literature and/or Proletarian Literature: Polemics of the Russian and Soviet Literary Left. Working-Class Literature(s): Historical and International Perspectives (eds. J. Lennon, M. Nilsson), Stockholm: Stockholm University Press, pp. 1-30.

Corney F. C. (1998) Rethinking a Great Event: The October Revolution as Memory Project. Social Science History, vol. 22, no 4, pp. 389-414.

Corney F. C. (2004) Telling October: Memory and the Making of the Bolshevik Revolution, Ithaca: Cornell University Press.

Criveller C. (2012) Introduction. AvtobiografiЯ, no 1, pp. 11-13.

Depretto J.-P. (2001) Ofitsial'nyye kontseptsii rabochego klassa v SSSR (1920-1930-e gg.) [The Official Concepts of the Working Class in the USSR (1920-1930s)]. Jekonomicheskaja istorija: Obozrenie. Vyp. 7 [Economic History: Review, Issue 7] (ed. L. I. Borodkin), Moscow, pp. 93-114.

Dobrenko E. (2007) Politjekonomiya socrealizma [Political Economy of Socialist Realism], Moscow: New Literary Observer.

Doktorov B. Z. (2013) Sovremennaya rossiyskaya sotsiologiya. Istoriya $v$ biografiyakh i biografii v istorii [Modern Russian Sociology: History in Biographies and Biographies in History], Saint Petersburg: EU Press. 
Doktorov B. Z. (2014) Biograficheskiye interv'yu s kollegami-sotsiologami. 4-ye dopolnennoye izdaniye [Biographical Interviews with Fellow Sociologists. 4th Supplemented Edition], Moscow: TsSPiM.

Doktorov B. Z. (2020) 15 let i 205 sudeb rossiyskikh sotsiologov: Fragmenty razvitiya istoriko-sotsiologicheskogo issledovaniya [15 years and 205 Fates of Russian Sociologists: Fragments of the Development of Historical and Sociological Research]. Available at: http://www.socioprognoz.ru/index.php?page_id=307\&fbclid=IwAR35dlInBN-QfLudu7jFz17wMObNvRqjxODe64ZY5h7nkyM7qY1_zLFFxA (accessed 6 April 2020).

Gaisinovich A. (1932a) Istochniki po istorii zavodov [Sources on the History of Factories]. The History of Factories, vol. 1, pp. 30-37.

Gaisinovich A. (1932b) (Beseda men'she vsego dolzhna pokhodit' na anketnyy opros) Istochniki po istorii zavodov [(The Conversation Should Least be Like a Questionnaire) Sources on the History of Factories]. The History of Factories, vol. 2.

G[aisinovich] A. (1932c) O rabote v arkhivakh [About Work in Archives]. The History of the Factories, vol. 3, pp. 148-152.

Ganzenmüller J. (2019) Osazhdennyy Leningrad. Gorod v strategicheskikh raschetakh agressorov $i$ zashchitnikov. 1941-1944. [Besieged Leningrad. The city in the strategic calculations of aggressors and defenders. 1941-1944], Moscow: Centerpolygraph.

Gilmintinov R. R. (2018) Institutsionalizatsiya Istprofov v strukture sovetskikh profsoyuzov [The Institutionalisation of Istprofs within the Structure of Soviet Trade Unions]. The Bryansk State University Herald, no 3, pp. 28-36.

Gilmintinov R. R. (2019a) Istprof $i$ osobennosti profsoyuznogo istoriopisaniya $v$ SSSR $v 1920$-ye gg. [Istprof and features of trade union historiography in the USSR in the 1920s] (PhD Thesis), Tomsk: Tomsk State University. Available at: http://vital.lib.tsu. ru/vital/access/manager/Repository/vtls:000661984 (accessed 5 April 2020).

Gilmintinov R. (2019b) "We can and we must": The Scientificitiy of Trade-Union History-Writing in the Soviet Union in the 1920s. Studia Historiae Scientiarum, vol. 18, pp. 219-254.

Golofast V. B. (1995) Mnogoobrazie biograficheskih povestvovanyi [Diversity of Biographical Narratives]. Sociological Journal, 1, pp. 71-89.

Gopius K. O storibankakh 100 let nazad. Vse ta zhe "Povest' o zhizni" [On the Story Banks 100 Years Ago. All the Same "Tale of Life"]. Yandex.Zen, 7 October 2019. Available at: https://zen.yandex.ru/media/id/5c584c0186e4a7ooadce84cb/o-storibankah10o-let-nazad-vse-ta-je-povest-o-jizni-5d9ado23d7859booaef4cc45 (accessed 5 April 2020).

Gorev B. I. (1930) Avtobiograficheskiy material kak istochnik izucheniya istorii proletariata SSSR [Autobiographical Material as a Source for Studying the History of the Proletariat of the USSR]. Istoriya proletariata SSSR, no 1, pp. 178-181.

Gorky M. (2018) Polnoye sobraniye sochineniy i pisem. T. 20: Pis'ma avgust 1930 - noyabr' 1931 [Complete Works and Letters, Vol. 20: Letters August 1930 - November 1931], Moscow: Nauka. 
Grekulov E. F. (1933) Arkhivy kak istochnik izucheniya istorii zavodov [Archives as a Source for Studying the History of Factories], Moscow: The History of Factories.

Grudtsova O. M. (1967) Aleksandr Bek: Kritiko-biogr. ocherk [Alexander Beck: Critical and Biographical Essay], Moscow: Soviet writer.

Hellbeck J. (ed.) (2015) Stalingradskaya bitva: svidetel'stva uchastnikov i ochevidtsev. Po materialam Komissii po istorii Velikoy Otechestvennoy voyny, 1941-1945 gg. [Battle of Stalingrad: Testimonies of Participants and Eyewitnesses: Based on Materials from the Commission on the History of the Great Patriotic War, 1941-1945], Moscow: New Literary Observer.

Hellbeck J. (2017) Revolyutsiya ot pervogo litsa: dnevniki stalinskoy epokhi [The First-Person Revolution: The Diaries of the Stalin Era], Moscow: New Literary Observer.

Inkeles A., Bauer R. A. (1959) The Soviet Citizen: Daily Life in a Totalitarian Society, Cambridge: Harvard University Press.

Ivanov M. A. (1989) Beseda kak metod sotsiologii [Conversation as a Method of Sociology]. Sociological Studies, no 4, pp. 106-111.

Ignatenko T. A. (1975) Izucheniye istorii rabochego klassa SSSR v institute istorii kommunisticheskoy akademii pri TSIK SSSR (1929-1935 gg.) [Studying the history of the working class of the USSR at the Institute of History of the Communist Academy at the Central Executive Committee of the USSR (1929-1935)]. History and Historians. 1973: Historiographic Yearbook, Moscow: Nauka, pp. 5-32.

Iokar L. (1957). Zhivyye traditsii ("Istoriya fabrik i zavodov") [Living traditions ("The History of Factories and Plants”)]. Problems of Literature, no 7, pp. 103-114.

Iroshnikov M.P., Zelenov M.V., Brandenberger D., Pivovarov N. Yu. (2018) Nekotoryye teoreticheskiye problemy izucheniya istorii grazhdanskoy voyny i varianty ikh resheniya v 1930-1935 gg. [Several Theoretical Problems during the Preparation of the History of the Civil War and its Various Solutions (1930- 1935)]. Modern History of Russia, vol. 8, no 2, pp. 487-506.

Junge M. (2015) Revolyutsionery na pensii: Vsesoyuznoye obshchestvo politkatorzhan i ssyl'noposelentsev: 1921-1935 [Retired Revolutionaries: The Society of Pre-revolutionary Political Convicts and Exiles: 1921-1935], Moscow: AIRO-XXI.

Kalinin I. (2015) Tam, gde konchayetsya dokument... [Where the document ends ...]. Stalingradskaya bitva: svidetel'stva uchastnikov i ochevidtsev. Po materialam Komissii po istorii Velikoy Otechestvennoy voyny, 1941-1945 gg. [Battle of Stalingrad: Testimonies of Participants and Eyewitnesses. Based on Materials from the Commission on the History of the Great Patriotic War, 1941-1945] (ed. J. Hellbeck), Moscow: New Literary Observer, pp. 627-645.

Kamensky V. V. (1918) Yego-moya biografiya velikogo futurista (7 dney predisloviy) [HisMy Biography of the Great Futurist (7 days of foreword)], Moscow: Kitovras.

Klopikhina V. S. (2019) Rabota istpartov Severnogo Kavkaza v sisteme realizatsii politiki pamyati sovetskoy vlasti v 1920-ye gody [The Work of the Istparts of the North Caucasus in the System of the Memory Policy of the Soviet Government in 1920s]. Humanities and Law Studies, no 3, pp. 59-69. 
Kodin E.V. (2003) "Garvardskiy proyekt" ["Harvard Project"], Moscow: ROSSPEN.

Kovalevsky V. A. (1939) Khozyain Trekh Gor [The Owner of the Three Mountains], Mocsow: Gosizdat.

Kovalevsky V. A. (1968) Tetradi iz polevoy sumki (Voyen. dnevnik) [Notebooks from the Map Case (Military Diary)], Moscow: Soviet writer.

Krasilnikova E. I. (2015) Pomnit' nel'zya zabyt'... Pamyatnye mesta i kommemorativnye praktiki v gorodakh Zapadnoy Sibiri (konets 1919 - seredina 1941 g.) [Either to forget or to remember ... Memorable places and commemorative practices in the cities of Western Siberia (the late 1919 - mid 1941)], Novosibirsk: Research Center of the National State Agrarian University "Golden Ear”.

Krasilnikova E. I. (2016) Pamyatnye mesta i kommemorativnye praktiki v gorodakh Zapadnoy Sibiri (konets 1919 - seredina $1941 \mathrm{~g}$.) [Memorable places and commemorative practices in the cities of Western Siberia (the late 1919 - mid 1941)] (PhD Thesis), Novosibirsk: Novosibirsk State Technical University.

Kruus H. H. (1971) Istoriya - sputnitsa naroda v Velikoy Otechestvennoy voyne [History - a companion of the people in World War II]. Voprosy istorii, no 5. pp. 123-129.

Kulachkov V. V. (2014) Krest'yanstvo Zapadnogo regiona Rossii v 1920-ye gg.: sotsiokul'turnyye izmeneniya [The Peasantry of the Western Region of Russia in the 1920s: Sociocultural Changes], Bryansk: BGITA Bryansk State Engineering and Technology Academy.

Kupriyanov L. A. (2008) Stanovleniye i razvitiye biograficheskikh issledovaniy v Pol'she [Formation and Development of Biographical Research in Poland]. Sotsiologiya vchera, segodnya, zavtra: Vtoryye sotsiologicheskiye chteniya pamyati Valeriya Borisovicha Golofasta [Sociology Yesterday, Today, Tomorrow: The Second Sociological Readings in Memory of Valery Borisovich Golofast] (ed. O. B. Bozhkov), Saint Petersburg: Bilbo, pp. 67-75.

Kurnosov A. A. (1974) Vospominaniya-interv'yu v fonde Komissii po istorii Velikoy Otechestvennoy voyny Akademii Nauk SSSR (organizatsiya i metodika sobiraniya) [Memoirs-interview in the fund of the Commission on the History of the Great Patriotic War of the USSR Academy of Sciences (organization and methodology of collecting)]. Archaeographic Yearbook for 1973, Moscow: Nauka, pp. 118-132.

Krandievsky S. I. (1932) Izuchay svoy zavod (V pomoshch' fabrichno-zavodskim krayevedcheskim yacheykam $v$ monograficheskom izuchenii svoyego predpriyatiya) [Study Your Plant (Aid to the Factory Cells of Local Lore in a Monographic Study of Their Enterprise), Moscow: Sovetskaya Aziya.

Kruglikov P. I. (1921) V poiskakh zhivogo cheloveka. Ocherk 1: Sovremennaya psikhologiya i yeye sblizheniye s naukami o kul'ture i obshchestve [In Search of a Living Man. Essay 1: Modern Psychology and Its Convergence with the Sciences of Culture and Society], Kazan: [Gos. izd-vo].

Lapitskaya S. M. (1935) Byt rabochikh Trekhgornoy manufaktury [Everyday Life of Workers of the Trekhgorny Manufactory] (ed. A. Gusev), Moscow: The History of Factories. 
Latoszek M. (1989) Zastosowanie metody biograficznej w dokumentowaniu faktów i stanów świadomości w okresie Sierpnia 1980 roku. Ruch Prawniczy, Ekonomiczny i Socjologiczny, no 2, pp. 277-294.

Lazareva E. V. (2011) Istparty i ikh vliyaniye na razvitiye ural'skoy istoricheskoy nauki [Istparty and Their Influence on the Development of the Ural Historical Science]. Istoriya nauki i tekhniki v sovremennoy sisteme znaniy [History of Science and Technology in the Modern Knowledge System], Ekaterinburg: UPI, pp. 73-79.

Lezhava L., Rusakov G. (1924) Pamyatnik bortsam proletarskoy revolyutsii, pogibshim v 1917-1921 gg. T. 1. Moskva: Gos. ed. 283 s. [Monument to the Fighters of the Proletarian Revolution who Died in 1917-1921, Vol. 1, Moscow: Gos. ed. 283 p.]. Proletarskaya revolyutsiya, no 11, pp. 283.

Litovskaya M. A. (1998) "Belomorsko-Baltiyskiy kanal imeni Stalina” kak etalonnyy tekst sotsialisticheskogo realizma (o knige "Belomorsko-Baltiyskiy kanal" pod red. M. Gor'kogo, L. Averbakha, S. Firina) [“The White Sea-Baltic Canal Named after Stalin" as a Reference Text of Socialist Realism (About the book "The White Sea-Baltic Canal”, eds. M. Gorky, L. Averbakh, S. Firin)]. Russkaya literatura XX veka: napravleniya i techeniya. Vyp. 4 [Russian Literature of the XX Century: Directions and Movements, Issue 4], Ekaterinburg, pp. 141-157.

Loginova N. A. (2001) Psikhobiograficheskiy metod issledovaniya i korrektsii lichnosti [Psychobiographic Method of Research and Personality Correction], Almaty: Kazak universiteti.

Loginova N. A. (2006) Nekotoryye itogi razvitiya biograficheskogo metoda v psikhologii v KHKH veke [Some Results of the Development of the Biographical Method in Psychology in the Twentieth Century]. Methodology and History of Psychology, vol. 1, no 2, pp. 67-81.

Lotareva D. D. (2014) Komissiia po istorii Velikoi Otechestvennoi voiny i ee arkhiv: Rekonstruktsiia deiatel'nosti i metodov raboty [The Commission on the History of the Great Patriotic War and Its Archive: Reconstruction of Activities and Working Methods]. Archaeographic Yearbook for 2011, Moscow: Nauka, pp. 123-166.

Malysheva S. (2001) Mif o revolyutsii 1917 goda: Pervyy sovetskiy gosudarstvennyy proyekt [The Myth of the 1917 Revolution: The First Soviet State Project]. Ab Imperio, no 1-2, pp. 285-303.

Mirskaya N. (1930) Krayevedcheskaya rabota na zavodakh i fabrikakh (zametki raz"yezdnogo instruktora) [Local History Work at Factories and Factories (Notes of a Traveling Instructor)]. Soviet Local History, no 7-8, pp. 29-32.

Moskovskaya D. S. (ed.) (2018) Istoriografiya Grazhdanskoy voyny v Rossii: issledovaniya i publikatsii arkhivnykh materialov [Historiography of the Civil War in Russia: Research and Publication of Archival Materials], Moscow: Institute of World Literature, Russian Academy of Sciences.

Narsky I. V. (2017) Sto let prevrashcheniy russkoy revolyutsii [100 Years of Transformations of the Russian Revolution]. History Studies, no 6, pp. 69-83.

Nevins A. (1938) The Gateway to History, New York: D. Appleton-Century Company. 
Novikova L. (2007) Frederick C. Corney, Telling October: Memory and the Making of the Bolshevik Revolution (Ithaca and London: Cornell University Press, 2004). xviii + 301pp. (Review). Ab Imperio, no 2, pp. 462-468.

Orlov I. B. (2010) Sovetskaya povsednevnost': istoricheskiy i sotsiologicheskiy aspekty stanovleniya [Soviet Everyday Life: Historical and Sociological Aspects of Formation], Moscow: HSE.

Panfilova A. M. (1974) The Status and Goals of Research into the History of Factories and Mills. Soviet Studies in History, no 4, pp. 62-94.

Pivovarov N. (2018) Iz zhizni "staroy gvardii”: Obshchestvo starykh bol'shevikov kak opyt politicheskoy adaptatsii revolyutsionerov (1922-1935 gg.) [From the Life of the "Old Guard": The Society of Old Bolsheviks as an Experience of the Political Adaptation of Revolutionaries (1922-1935)]. Russia XXI, no 1, pp. 50-81.

Pokrovsky M. N. (1924a) Dvadtsatiletiye nashey pervoy proletarskoy revolyutsii [Twentieth Anniversary of Our First Proletarian Revolution]. Proletarskaya revolyutsiya, no 11 , pp. 5-13.

Pokrovsky M. N. (1924b) Proyekt ankety po revolyutsii pyatogo goda (Prilozheniye k stat'ye M. Pokrovskogo) [Draft Questionnaire on the Fifth Year Revolution (Appendix to the Article by M. Pokrovsky)]. Proletarskaya revolyutsiya, no 11, pp. 14-18.

Postanovleniye TSBK o "krayevedcheskoy pyatidnevke" (1930) [Decree of the the Central Bureau of Local History on the "Local History Five-Day"]. Soviet Local History, no 3-4, pp. 55-56.

Pravila konkursa na luchsheye sochineniye o fabrike ili zavode (1930) [Competition Rules for the Best Essay about a Factory or Plant]. Soviet Local History, no 1-2, pp. 96-97.

Programma po istorii Oktyabr'skikh zheleznykh dorog (1933) [Program on the History of the October Railways], Moscow: The History of Factories.

Promyshlennaya sektsiya (1930) [Industrial section]. Soviet Local History, no 6, p. 30.

Pyatigorskiy krayeved: opyt "avtobiografii” kolkhoza (1931) [Pyatigorsk Local Historian: An Attempt of the "Autobiography" of the Collective Farm]. Soviet Local History, no 10, pp. 31-33.

Rudenko N. (2017) Polnotekstovaya baza dannykh «Vospominaniya starykh rabochikh obshchestva mekhanicheskikh zavodov br. Bromley i metallurgicheskogo zavoda Guzhona»: opyt razmetki slabostrukturirovannogo istochnika [Full-Text Database "Society of Mechanical Plants of br. Bromley and Metallurgical Plant Goujon old Workers' Memoirs": Experience of Marking Semi-Structured Source]. ISTORIYA, vol. 8, no 7. Available at: https://history.jes.su/s207987840001947-0-1/ (accessed 5 April 2020).

Rabinovich I. (1933) O zapisi vospominaniy: Iz opyta raboty t. S. Mirera [On the Record of Memoirs: From the Experience of Comrade S. Mirer]. The History of Factories, no 4-5, pp. 205-215.

Rogachevskaya L. S. (1963) Nekotoryye itogi izucheniya istorii fabrik i zavodov [Some Results of the Study of the History of Factories and Plants]. Voprosy istorii, no 3, pp. 109-119. 
Rogozin D. M. (2015) Biograficheskiy metod: obzor literatury [Biographical Method: Literature Review]. Sociological Studies, no 10, pp. 120-129.

Rozanov M. D. (ed.) (1958) Sozdadim istoriyu zavodov Leningrada [Let's Create the History of the Factories of Leningrad], Leningrad: Lenizdat.

Rozhkova M. (1930) Trekhgornaya manufaktura ko vremeni revolyutsii 1905 goda [Trekhgorny Manufactory by the Rime of the Revolution of 1905]. Rabochiye Trekhgornoy manufaktury v 1905 godu [Workers of Trekhgorny Manufactory in 1905], Moscow: Publishing House of the Communist Academy, pp. 7-26.

Rozhkova M. (1932) Kak zapisat' vospominaniya [How to Record Memories]. The History of Factories, no 3.

Rozhkova M. K. (1933a) Ob izuchenii truda i byta rabotnits (v kapitalisticheskuyu epokhu) [On the Study of the Labor and Life of Women Workers (in the Capitalist Era)], Moscow: The History of Factories.

Rozhkova M. K. (1933b) Kak izuchat' zarabotnuyu platu i polozheniye rabochikh $v$ epokhu kapitalizma [How to Study the Wages and Position of Workers in the Era of Capitalism], Moscow: The History of Factories.

Rybnikov N. A. (1918) Biograficheskiiy institut [Biographical Institute], Moscow.

Rybnikov N. A. (1920) Biografii i ikh izucheniye [Biographies and Their Study], Moscow.

Rybnikov N. A. (1926) Detskiye risunki i ikh izucheniye [Children's Drawings and Their Study], Moscow: Gosizdat.

Rybnikov N. A. (1928) Yunosheskiye dnevniki i ikh izucheniye [Youth Diaries and Their Study]. Psychology, vol. 1, no 2, pp. 83-95.

Rybnikov N. A. (1930) Avtobiografii rabochikh i ikh izucheniye: Materialy $k$ istorii avtobiografii kak psikhologicheskogo dokumenta [Workers' Autobiographies and Their Study: Materials for the History of Autobiography as a Psychological Document], Moscow: Gosizdat.

Rybnikov N. A. (1943) Iz roda v rod. Istoriya sem'i Rybnikovykh (Za dvukhsotletniy period yeye sushchestvovaniya). Ch. II: Pyatoye pokoleniye. Avtobiografiya N. A. Rybnikova [From Generation to Generation: History of the Rybnikov Family (Of the Two-Hundred-Year Period of Its Existence). Part II: Fifth generation. Autobiography of N. A. Rybnikov]. The Russian State Library, Department of manuscripts, f. 367, carton 4, item. 2.

Rybnikov N. A. (1942) Iz roda v rod. Istoriya sem’i Rybnikovykh (Za dvukhsotletniy period yeye sushchestvovaniya). Ch. III. Pyatoye pokoleniye. Avtobiografiya N. A. Rybnikova [From Generation to Generation: History of the Rybnikov Family (Of the Two-Hundred-Year Period of Its Existence). Part III: Fifth Generation. Autobiography of N. A. Rybnikov]. The Russian State Library, Department of manuscripts, f. 367, carton 8 , item 2.

Rybnikov N. A. (1994) Iz avtobiografii N. A. Rybnikova - odnogo iz pervykh sotrudnikov Psikhologicheskogo instituta [From the Autobiography of N. A. Rybnikov, One of the First Employees of the Psychological Institute]. Voprosy Psychologii, no 1, pp. 11-16. 
Rybnikov N. A. (2015) Biografii i ikh izucheniye [Biographies and Their Study]. Avantgarde museology (ed. A. Zhilyaev), Moscow: V-A-C press, pp. 172-180.

Rybnikova M. A. (1919) Gorbovskaya khronika po arkhivu sem’i Shchukinykh [Gorbovsky Chronicle from the Shchukin Family Archive], Moscow.

Shcheglova T. K. (2019) Materialy ustnoy istorii kak istoricheskiy istochnik i poiski im mesta $\mathrm{v}$ nauchnykh klassifikatsiyakh rossiyskogo istochnikovedeniya v XX-XXI stoletiyakh [Oral History Materials as a Historical Source and Search for Their Places in Scientific Classifications of Russian Source Study in the 20-21st Centuries]. Vestnik Altaiskogo Gosudarstvennogo Pedagogiceskogo Universiteta, no 41, pp. 93-101.

Shcheglova T. K., Drozhetsky D. F. (2014) Ustnaya istoriya (Oral history) v rossiyskoy istoricheskoy praktike 1920-1930-kh gg.: k diskussii o ponyatii i vremeni vozniknoveniya ustnoy istorii [Oral History in the Russian Historic Research of the 1920-1930s: Discussion of the Concept of "Oral History" and Its Time of Origin]. Izvestiya of Altai State University, Series: History. Political Science, no 4/2, pp. 254-260.

Shushkanov N. (1932) Kak idet rabota po "Istorii zavodov" [How is the Work on "The History of Factories" Going]. Krasnaya nov', no 8, pp. 177-183.

Sieca-Kozlowski E. (2019) Soviet \& Post-Soviet Wars: An Oral History Project. The Journal of Power Institutions in Post-Soviet Societies, no 20-21. Available at: http://journals. openedition.org/pipss/5856 (accessed 5 April 2020).

Sklyarenko E. M. (1986) Istoriya fabrik i zavodov Ukrainskoy SSR: Istoriografiya problemy [The History of the Factories and Plants of the Ukrainian SSR: Historiography of the Problem], Kiev: Naukova Dumka.

Smirnova M. A. (2016) Zhurnal "Krayeved-massovik" (Moskovskaya oblast') i realii krayevedeniya nachala 1930-kh godov [Magazine "Local Lore-Massik" (Moscow Region) and the Realities of Local History in the Early 1930s]. RSUH/RGGU Bulletin: Series "Literary Theory. Linguistics. Cultural Studies", no 10, pp. 9-34.

Sobiraniye avtobiografiy i vospominaniy uchastnikov revolyutsii 1917 g. i grazhdanskoy voyny (1931) [Collecting of Autobiographies and Memoirs of the Participants in the 1917 Revolution and Civil War]. Istoriya proletariata SSSR, no 8, pp. 185-191.

Sobolev G. L. (2012) Blokada Leningrada: postizheniye pravdy [The Blockade of Leningrad: Comprehension of the Truth]. Modern History of Russia, no 2, pp. 72-87.

Sobolevskaya O. V. (2019) Pamyat' kak uchastiye: Kak lichnyye arkhivy konstruiruyut novuyu istoriyu [Memory as Participation: How Personal Archives Design a New History]. IQ: Research and Education, 16 January. Avalable at: https://iq.hse.ru/ news/231962189.html (accessed 5 April 2020).

Solovyev G. E. (2002) Biograficheskiy metod $v$ deyatel'nosti sotsial'nogo pedagoga $i$ sotsial'nogo rabotnika [Biographical Method in the Activities of a Social Educator and Social Worker], Izhevsk: Udmurt State University.

Spiridonova L. (2016) Golos istorii v tvorchestve Gor'kogo [Voice of History in Gorky's Work]. Gorky: Uroki Istorii: Gorkovskie Chtenija 2014 [Gorky: History Lessons: Gorky Readings of 2014], N. Novgorod: BegemotNN, pp. 4-13. 
Surzhikova N. V. (2017) Rossiya 1917 goda v otechestvennykh i zarubezhnykh ego-dokumentakh [Russia in 1917 in Domestic and Foreign Ego-Documents]. Bulletin of the Russian Foundation for Basic Research Humanitarian and Social Sciences, no 4, pp. $25-34$.

Surzhikova N.V. (2020) SOSEDI PO PERMI: Lektsiya Natal'i Surzhikovoy [NEIGHBORS OF PERM: Lecture by Natalia Surzhikova]. Avalable at: https://www.youtube.com/ watch?v=va51KFRce5w (accessed 5 April 2020).

Thompson P. (1994) Gumanisticheskaya traditsii i zhiznennyye istorii v Pol'she [Humanistic Traditions and Life Stories in Poland]. Biograficheskiy metod v sotsiologii: istoriya, metodologiya i praktika [Biographical Method in Sociology: History, Methodology and Practice], Moscow: Institute of Sociology RAS, pp. 51-62.

Toom L (ed.) (1934) Kuznetskstroy (Istoriya Kuznetskstroya v vospominaniyakh) [Kuznetskstroy (History of Kuznetskstroy in Memoirs)], Novosibirsk: Zap.-Sib. krayev. izd-vo.

Transcript of the meeting of the Bureau and the activ of the sections of prose and essay and scientific and fiction literature of the Moscow Branch of the USSR Writers Union on the resumption of the series "The History of Factories and Plants" (1954) May 13. The Russian State Archive of Literature and Arts, f. 2464, inv. 1, item 342.

Tretyakov I. N., Lavrov N., Suslova E. (1933) ... O rabote v arkhivakh Leningrada po istorii zavodov [...On the Work in the Archives of Leningrad on the History of Factories], Moscow: The History of Factories.

Tsvetkova G. A. (2016) O derevenskoy samobytnosti: zabytoye, no ochen' vazhnoye issledovaniye 1920-kh gg. [On Village Identity: A Forgotten, but Very Important Study of the 1920s]. Sociological Studies, no 12, pp. 114-122.

Vasilieva N. F. (2011) Nekotoryye syuzhety deyatel'nosti izdatel'stva Obshchestva politkatorzhan: politicheskiye i organizatsionnyye trudnosti [Some Facts of the Activity of the Publishing Company of the Political Exiled Society: Political and Organizational Difficalties]. The Bulletin of Irkutsk State University. Series "Political Science and Religion Studies", no 1, pp. 247-254.

Vernyaev I. I. (2005) Lokal'nyye monograficheskiye issledovaniya derevni 1920-1930-kh godov: tseli, metodiki, rezul'taty [Local Monographic Studies of the Village of the 1920-1930s: Goals, Methods, Results]. Problemy istoricheskogo regionovedeniya [Problems of Historical Regional Studies] (ed. Y. V. Krivosheyev), Saint Petersburg: SPBU, pp. 29-64.

Veselkova N., Pryamikova E., Vandyshev M. (2016) Mesta pamjati v molodyh gorodah [Sites of Memory in Young Towns], Ekaterinburg: Ural State University.

Veselkova N. V. (2017) Istoriya fabrik i zavodov Alekseya Malen'kogo: portret i proyekt [The History of Factories and Plants by Alexey Malenkiy: Portrait and Project]. Epokha sotsialisticheskoy rekonstruktsii: idei, mify i programmy sotsial'nykh preobrazovaniy [The Epoch of Socialist Reconstruction: Ideas, Myths and Programs of Social Transformations] (eds. O. V. Gorbachev, L. N. Mazur), Ekaterinburg: Ural State University. 
Veselkova N. V. (2018) “Moi pis'ma ni v koyem sluchaye nel'zya rastsenivat' kak document": pis'mo kak (pub)lichnyy zhanr ["In no case can my letters be regarded as a document": A Letter as a Public/Personal Genre]. Arkhiv v sotsiume - sotsium $\checkmark$ arkhive: materialy regional'noy nauchno-prakticheskoy konferentsii [Archive in Society - Society in the Archive: Proceedings of a Regional Scientific and Practical Conference] (ed. N. A. Antipin), Chelyabinsk: United State Archive of the Chelyabinsk Region, pp. 207-211.

Zak L. M., Gorodetsky E. N. (1987) Akademik I. I. Mints kak arkheograf (k 9o-letiyu so dnya rozhdeniya) [Academician I. I. Mints as an Archaeographer (On the Occasion of His 9oth Birthday)]. Archaeographic Yearbook for 1986, Moscow: Nauka, pp. 131-142.

Zak L. M., Zimina S. S. (eds.) (1959) A. M. Gorky $i$ sozdaniye istorii fabrik $i$ zavodov: Sbornik dokumentov $i$ materialov $v$ pomoshch' rabotayushchim nad istoriyey fabrik i zavodov SSSR [A. M. Gorky and the Creation of the History of Factories and Plants: A Collection of Documents and Materials to Help those Working on the History of Factories and Plants of the USSR], Moscow: Sotsekgiz.

Zelenov M. V., Brandenberger D. (eds.) (2017) Istoriya grazhdanskoy voyny v SSSR (1935 g.): istoriya teksta $i$ tekst istorii [The History of the Civil War in the USSR (1935): The History of the Text and the Text of History], Moscow: ROSSPEN.

Zhadaeva N. F. (2018) A. M. Gor'kiy “Istoriya fabrik i zavodov": zamysel i voploshcheniye [A. Gorky's "History of Factories and Plants": Design and Implementation]. Nizhny Novgorod Museum, no 32, pp. 106-121.

Zhuravlev S. V. (1989) K voprosu o roli TSAU SSSR i RSFSR v vyyavlenii dokumentov po istorii fabrik i zavodov SSSR v 1930-ye gody [On the Role of the CAO of the USSR and the RSFSR in the Identification of Documents on the History of Factories and Plants of the USSR in the 1930s]. Archaeographic Yearbook for 1988, Moscow: Nauka, pp. $185-195$.

Zhuravlev S. V. (1997) Fenomen "Istorii fabrik i zavodov": gor'kovskoe nachinanie v kontekste epokhi 1930-kh gg. [The Phenomenon of "The History of Factories and Plants": Gorky's Initiative in the Context of the 1930s], Moscow: Institute of Russian History, Russian Academy of Sciences.

Zhuravlev S. V. (ed.) (2015) Vklad uchenykh-istorikov v sokhraneniye istoricheskoy pamyati o Velikoy Otechestvennoy voyne. Na materialakh Komissii po istorii Velikoy Otechestvennoy voyny AN SSSR, 1941-1945 gg. [The Contribution of Historians to the Preservation of Historical Memory of the Great Patriotic War. Based on the Materials of the Commission on the History of the Great Patriotic War of the Academy of Sciences of the USSR, 1941-1945], Moscow: Center for Humanitarian Initiatives. 


\title{
Биографический метод как методологическая традиция в отечественной практике: обзор проектов и публикаций
}

\author{
Наталья Веселкова \\ Кандидат социологических наук, доцент, Уральский федеральный университет имени первого \\ президента России Б. Н. Ельцина \\ Адрес: пр. Ленина, д. 51, г. Екатеринбург, Российская Федерация 620083 \\ E-mail: vesselkova@yandex.ru
}

Биографический метод считается прочно укорененным в западной традиции первой половины XX в. (Чикагская школа социологии, начатые Ф. Знанецким польские конкурсы памяти); отечественный опыт не интегрируется и не замечается. Поэтому возникший в 1990-е гг. всплеск интереса к биографическим исследованиям выглядит основанным на вовлечении наработанных исключительно за рубежом методологий. Вместе с тем, в России в тот же период имело место во многом сходное движение. В статье представлен аналитический обзор шести сюжетов этого движения и их современной рецепции: 1) Биографический институт Рыбникова, 2) исторические комиссии и общества - Истпарты и др., 3) Комакадемия, 4) Центральное Бюро Краеведения и др., 5) История гражданской войны и История фабрик и заводов, Кабинеты записей и мемуаров, 6) Комиссия по истории Великой Отечественной войны. Известные специалистам, все эти начинания до сих пор изучались узкодисциплинарно и почти безотносительно к биографическому методу. Рассмотрение развернутого ряда этих сюжетов в контексте биографического метода дает новую оптику, выявляя общие эффекты биографизирования как саморефлексии модерного общества, с участием академической науки и без нее. Обзор построен с учетом исторических реалий и в междисциплинарном поле. В анализируемых проектах прослеживается внутренняя преемственность, к их общим чертам отнесены: артикуляция социальной актуальности, темпоральный режим, особенности организации работы и методологические характеристики, которые детализируются особо на предмет релевантности методологическим установкам современной социально-гуманитарной науки.

Ключевые слова: биографирование, устная история, воспоминания, интервью, условия научности, Николай Рыбников, Александр Бек, историзация на марше, романтический позитивизм 